\title{
The Importance of Non-Profit Organization in Globalized World: International Comparison of American and European Continent
}

\author{
Viera Bartosova ${ }^{1}$, and Ivana Podhorska ${ }^{1, *}$ \\ ${ }^{1}$ University of Zilina, Faculty of Operation and Economics of Transport and Communications, \\ Department of Economics, Univerzitna 1, 01026 Zilina, Slovakia
}

\begin{abstract}
.
Research background: In developed countries, we see a significant increase in the importance of non-profit organizations thank to public initiative. The primary objective is to improve the quality of life in society. Cooperation between private, public and non-profit sectors creates synergy effects. The primary problems of non-profit organizations include legislation that does not sufficiently motivate entrepreneurs to support nonprofit subjects, but also a shortage of employees and volunteer.

Purpose of the article: Despite the fact that, under the conditions of globalization, there is a greater interconnection of the economies of individual countries, also in the area of non-profit sector, there is still exist important differences between the operation and importance of non-profit organization in an American and European continent.

Methods: Firstly, theoretical part of the paper provides historical development of non-profit sector based on primary theoretical approaches. Secondly, practical part of the paper describes non-profit sector on American and European continent. In other words, the paper summarises theoretical and empirical knowledge on importance of non-profit sector in various countries around all the world. Paper main aim is the highlighted the importance of non-profit sector under the conditions of globalization with the emphasis on the international comparison of American and European point of view.

Findings \& Value added: The results show that non-profit sector plays significant role in building national economies. This paper is the one part of the project outputs focused on non-profit sector. In developed countries, we see a significant increase in the importance of non-profit organizations thank to public initiative.
\end{abstract}

Keywords: non-profit organization; non-profit sector; non-profit theory; globalization

JEL Classification: $F 6$; $G 3$

\footnotetext{
* Corresponding author: ivana.podhorska@,fpedas.uniza.sk
} 


\section{Introduction}

In developed countries, we see a significant increase in the importance of non-profit organizations thank to public initiative. The primary objective is to improve the quality of life in society. Okuneviciute Neverauskiene and Pranskeviciute (2018) stress that cooperation between private, public and non-profit sectors creates synergy effects. Nonprofit organizations are active mainly in social care and education. [1] Donnelly (2017) analyses the interaction between online and face-to-face problem-based learning tutorials in higher education. [2] Moreover, in the US, the education costs are relative high. Popescu and Ciurlau (2017) assess the success of financial assistance in promoting higher education. [3] The boom of non-profit organizations is influenced by the external environment in the form of development agencies and state support. Kliestik, Misankova, Valaskova and Svabova (2018) claim that organizations have economic and moral responsibility for stakeholders. [4] Nowadays, many businesses are aware not only of economic roles but also of moral responsibility. These attributes affect business goodwill. Kliestik, Kovacova, Podhorska and Kliestikova (2018) focused only on economic factors. These authors created an economic model that includes key factors such as return on equity, net profit from previous years, retained earnings, valuables, marketing costs and investments to the plant as relevant indicators of enterprise goodwill creation. [5] Moreover, many companies cooperate with non-profit organizations for improving sustainable in civic society. In addition, Leber, Ivanisevic, Borocki, Radisic and Slusarczyk (2018) deal with how customers can influence a sustainable product. [6] Olah, Zeman, Balogh and Popp (2018) claim that sustainable product can be improved by IT tools. [7] Non-profit organizations are dynamic and flexible entities, contributing to effective functioning, particularly in the social and educational spheres. The primary problems of non-profit organizations include legislation that does not sufficiently motivate entrepreneurs to support non-profit subjects, but also a shortage of employees and volunteers. On the other hand, Andersson, Bridi, Baez, Maldonado, Forcellini and Moraes (2018) explain that public sector is characterised by bureaucracy. Their aim was to create model to improve public service. [8]

\section{Methodology}

The origin of non-profit organizations is explained by many economic theories, namely theory of governmental and market failures (theory of public goods), contract failure theory, welfare state theory, interdependence theory and social origins theory.

Theory of governmental and market failures (theory of public goods) is one of the key theories of the non-profit sector. This theory is based on the theory of heterogeneity (supply side theory), which is related to the market failure theory and government failure theory in the provision of public services. According to Olson Theory, the main reason for market failure is the inability of individuals to cooperate. Many states with a democratic system are trying to satisfy the so-called median voter. This means that many of population needs are not satisfied by the state and the market. These circumstances have created a space for nonprofit organizations. Critics point out that some non-profit organizations do not arise due to an inefficient market mechanism, and not every non-profit organization is successful. [9]

Contract failure theory. According to this theory, the consumer does not have much information for assessment of the quality and availability of goods and services. Therefore, consumer seeks to find a trusted provider to minimize the consequences of information asymmetry. Critics of the theory point to the assumption that entrepreneurs abuse information asymmetry, which may not be true. On the other hand, certain manifestations of unserious behaviour may also occur in non-profit organizations. [9] 
Welfare state theory. In the past, non-profit organizations have arisen because of an undeveloped welfare state. Non-profit organizations partly address marginal (residual) social problems. The theory assumes that the importance of non-profit organizations will diminish in the future due to the improvement of the market mechanism and the strengthening of the state's responsibility. According to the welfare state theory, non-profit organizations represent a residual that only compensates for a set of services provided by the state and the market. [10]

Furthermore, interdependence theory was proposed by Thibaut and Kelley (1959). According to the theory, the non-profit public sector and the non-profit private sector are interdependent. They can cooperate in the production of mixed collective assets. Based on empirical studies, we can argue that cooperation arises especially in health care, education and social services. The theory of three sectors emphasizes that the non-profit sector responds more flexibly to changes in demand for services compared to state organizations. [11]

This theory is based on cooperation. Nevertheless, non-profit organizations may fail. The primary reasons include:

- philanthropic insufficiency means that non-profit organizations have a lack of volunteers and resources for operation.

- philanthropic paternalism means that the ideas of non-profit organizations differ with the expectations of the recipients of assistance.

- philanthropic amateurism means that there is not enough qualified staff in non-profit organizations. Most volunteer organizations are mostly volunteers. The reason is lack of funds.

- philanthropic particularism means that non-profit organizations focus on a specific area of assistance, not cooperating to solve other problems. Thus, non-profit organizations are oriented towards partial parts rather than the complex nature of services. [10]

Social origins theory is presented by B. Moore (1993). This theory is considered significant because Johns Hopkins University researchers compared the non-profit sector in various countries. The research idea was to explain current events based on the past. L. M. Salomon and H. K. Anheier (1998) suggested models of relationships based on comparisons of relations between the public, commercial and non-profit sectors. Salamon and Anheier argue that the non-profit sector in different countries has a different historical beginning and reveals various social and economic aspects. These models deal with the extent and intensity of co-operation of individual sectors in addressing problems in the provision of mixed collective assets. Salomon and Anheier (1998) deal with two variables, namely government social spending and the non-profit sector economic size. [11] Based on the results of the study, the authors defined a liberal, social-democratic, corporatist and statist model of the relationship between state and non-profit sector.

- The liberal model is characterized by the low social costs of the state and a high share of NGO funding. It is based on a private initiative and voluntary basis. This model is mainly applied in countries with a high level of middle-level representation, which is not interested in raising social benefits, for instance, USA and United Kingdom.

- The socio-democratic model is typical of high public spending on social benefits. There is little scope for non-profit organizations. Based on these facts, Stejskal, Kuvikova and Matatkova (2012) claim that the social-democratic model is the opposite of the liberal model. The state provides social services using its own facilities. Socio-democratic model is applied by Scandinavian countries.

- The corporatist model represents a combination of previous models. This model is characteristic of the large non-profit sector in the existence of social programs that the state finances. Social services are implemented through state and private non-profit 
organizations (subsidiary model). Germany, Belgium, Netherlands, Austria and France apply this model.

- The static model is the opposite of the corporatist model. It is characterized by low third-sector scope and low social spending by the state. Non-profit organizations are dealing with marginal interests and are being printed on the periphery of interest by government institutions. It is the result of a long-term high number of farmers in the national economy and a low industrialization rate. Japan and Brazil belong to the countries applying this model. [10]

\section{Results}

United States of America. In 2013, the total income of US non-profit organizations reached more than 2.26 billion USD and the total assets amounted to more than 5.17 billion USD. We see healthy financial developments between 2003 and 2013, because total revenues and assets rose faster than GDP. Most of non-profit organizations consist of public charities with more than 30 types of non-profit organizations exempt from income tax. Public charities are made up of artistic, cultural, humanitarian, educational, health organizations and organizations to protect human services. Specifically, in 2013, public charities represented more than 950,000 organizations, representing $67.5 \%$ of non-profit organizations. The number of registered public charities grew faster than other non-profit organizations, while private foundations declining by $8.3 \%$. Most of public charity revenue is generated by fees for services and goods from private sources, which is almost $47.5 \%$. Another significant revenue is government revenue $(24.5 \%)$. Furthermore, private charitable donations account for $13.3 \%$ of total revenues and state subsidies represent $8 \%$. [12]

Foundation Center (2014) reports that the number of US foundations has risen steadily since 2003, apart from the economic crisis in 2010-2011. In 2012, the number of foundations was 82,192 divided into independent foundations, operating foundations operating foundations, corporate foundations, and community foundations. [13]

Canada. National Survey of Nonprofit and Voluntary Organizations (2005) states that in 2003, approximately 161,000 Canadian non-profit and voluntary organizations have employed more than 2 million workers. In addition, more than 19 million volunteers. Interestingly, many non-profit organizations rely heavily on volunteers. It is confirmed by the fact that $54 \%$ of non-profit organizations do not employ any paid employee. [14] Imagine Canada (2017) indicates Canada's non-profit sector is the second largest in the world, on the first place is Netherlands. There are approximately 170,000 Canadian nonprofit organizations where volunteers represent a significant group of workers. In addition, the Canadian non-profit sector contributes $8.1 \%$ to GDP, representing a larger share than the automotive or manufacturing industry. [15]

Turcotte (2015) states that in 2013, 12.7 million Canadians aged over 15 (44\%) worked as volunteers, working together for nearly 2 billion hours. However, from time perspective, we can see a smaller decrease, as in previous years the level of volunteering for the public over 15 years was higher, in 2004 (45\%), in 2007 (46\%) and in 2010 (47\%). Furthermore, the average number of hours worked per volunteer is 154, which is at least since 2004. Moreover, more than $80 \%$ of Canadians donated a financial contribution to a charity or non-profit organization. Although the number of contributors decreased by $2 \%$, the total increased by $14 \%$ to $\$ 12.8$ trillion in 2013 compared to 2010 . [16]

On the European continent, specifically in the United Kingdom, Phoaraoh, Goddard and Jenkins (2014) wrote study about charitable income and spending in the 100 family foundations and family trusts. These authors demonstrate that most of the funds $(56 \%)$ come from family foundations in non-profit sector, unlike the US. [17, 18, 19] 
United Kingdom. Association of Charitable Foundations (ACF) brings together more than 300 foundations and charitable funds in connection with grants. Pharoah, Jenkins, Goddard and Walker (2016) claim in the publication "Foundation Giving Trends 2016" that independent charitable foundations provide an effective, transparent and yet deliberate way of irreversible transformation of private wealth into a publicly beneficial character. Many foundations help volunteer sector, but foundations are not limited to funding registered charities, social enterprises, universities, individuals and public and private sector bodies. They estimate that funding through charitable foundations accounts for $15 \%$ of the total revenues. Interestingly, in 2015, the total was down to 17.8 billion GBP from 19 billion GBP in previous year. This decline is probably associated with a decline in public confidence in non-profit organizations. [17, 20, 21]

Czech Republic. Neziskovky.cz (2017) states that non-profit organizations are nonprofit-making organizations for redistribution between owners, trustees or founders. It means that profit is used to develop the organization and fulfil the mission of non-profit organization. Since the beginning of 2014, the recodification of private law regulating nonprofit organizations has entered into force in the Czech Republic. Later, the name of the civic associations was changed to the societies. Furthermore, foundations and endowment funds concentrate on collecting assets for given purpose. [22, 23, 24]

\section{Discussion and Conclusion}

The origin of non-profit organizations is explained by various economic theories, such as government and market failures theory, information asymmetry theory, welfare state theory, interdependence theory and sector coexistence model. In our opinion, the theory of government and market failures best explains the origin of the non-profit sector. [25]

As has been mentioned, the number of non-profit organizations is constantly rising in several developed countries. For the primary reason, we consider the inability of market players and government institutions to respond flexibly to public demands. This is confirmed by the fact that non-profit organizations occur mainly in neglected areas such as health, education, environmental protection, etc. On the other hand, we do not agree with the ideas of the welfare state theory, according to which the number of non-profit organizations will decrease with strengthening the responsibility of states. The reason is that many state institutions rely solely on non-profit organizations and ultimately replace the state in fulfilling their elementary obligations.

Grant No. 1/0544/19 Formation of the methodological platform to measure and assess the effectiveness and financial status of non-profit organizations in the Slovak Republic.

\section{References}

1. Okuneviciute Neverauskiene, L., Pranskeviciute, I. (2018). Overcoming paradox for social enterprise definition: Case of Lithuania. Ekonomicko-manazerske spektrum, 12(1), 104-118.

2. Donnelly, R. (2017). Blended problem-based learning in higher education: The intersection of social learning and technology. Psychosociological Issues in Human Resource Management, 5(2), 25-50.

3. Popescu, G. H., Ciurlau, F. C. (2017). The skyrocketing costs of U.S. higher education and the student debt crisis. Psychosociological Issues in Human Resource Management, 5(1), 242-248. 
4. Kliestik, T., Misankova, M., Valaskova, K., Svabova, L. (2018). Bankruptcy prevention: New effort to reflect on legal and social changes. Science and Engineering Ethics, 24(2), 791-803.

5. Kliestik, T., Kovacova, M., Podhorska, I., Kliestikova, J. (2018). Searching for key sources of goodwill creation as new global managerial challenge. Polish Journal of Management Studies, 17(1), 144-154.

6. Leber, M., Ivanisevic, A., Borocki, J., Radisic, M., Slusarczyk, B. (2018). Fostering alliances with customers for the sustainable product creation. Sustainability, 10(9), 3204.

7. Olah, J., Zeman, Z., Balogh, I., Popp, J. (2018). Future challenges and areas of development for supply chain management. Logforum, 14(1), 127-138.

8. Andersson, R., Bridi, E., Baez, Y. P., Maldonado, M. U., Forcellini, F. A., Moraes, F. C. (2018). Improvement in public administration services: A case of business registration process. International Journal of Industrial Engineering and Management, 9(2), 109-120.

9. Siekelova, A. (2015). The role of the receivables management in conditions of globalization. In T. Kliestik (Ed.), Proceeding of the 15the International Scientific Conference on Globalization and its Socio-Economic Consequences (pp. 686-690). Rajecke Teplice, Slovakia.

10. Siekelova, A., Kovacova, M., Adamko, P. et al. (2019). Profit management as an instrument for SMEs developing: The case for Slovakia. Marketing and Management of Innovations, 3, 285-296.

11. Anheier, H. K. (2005). Nonprofit organizations: Theory, management, policy. London: Routledge.

12. McKeever, B. (2015). The nonprofit sector in brief 2015: Public charities, giving and volunteerting. Retrieved from : http://www.urban.org/research/publication/nonprofitsector -brief-2015-public-charities -giving-and-volunteering

13. Foundation Center, Foundation Research (2014). Retrieved from: http:/foundationcenter.org/ gainknowledge/research/keyfacts2014/foundationfocus.html

14. Statistics Canada, highlights of the national survey of nonprofit and voluntary organizations. (2005). Ottawa: Minister responsible for Statistics Canada.

15. Imagine Canada, Key Facts about Canada's Charities (2017). Retrieved from: http://www.imaginecanada.ca/resources-and-tools/research-and-facts/key-facts-aboutcanada $\% \mathrm{E} 2 \% 80 \% 99$ s-charities

16. Turcotte, M. (2015). Spotlight on Canadians: Results from the general social survey. volunteering and charitable giving in Canada. Retrieved from: http://www.statcan.gc.ca/pub/89-652-x/89-652-x2015001-eng.pdf

17. Phoaraoh, C., Goddard, K., Jenkins, R. (2014). Giving trends top 100 family foundations 2015. Retrieved from: http://www.acf.org.uk/downloads/publications/Family_Foundation_Giving _Trends_2015_FINAL.pdf

18. Slattery, C., Zidar, O. (2020). Evaluating state and local business incentives. Journal of Economic Perspectives, 34(2), 90-118.

19. Ma, L., Ruzic, D. (2020). Globalization and top income shares. Journal of International Economics, 125, 103312. 
20. Connelly, B. L, Shi, W., Hoskisson, R. E. et al. (2019). Shareholder influence on joint venture exploration. Journal of Management, 45(8), 3178-3203.

21. Bennett, V. M. (2020). Changes in persistence of performance over time. Strategic Management Journal, 41(10), 1745-1769.

22. Cumming, M. E., Rawhouse, H., Vismara, S. et al. (2020). An equity crowdfunding research agenda: Evidence from stakeholder participation in the rulemaking process. Small Business Economic, 54(4), 907-932.

23. Barrot, J.-N., Loualiche, E., Sauvagnat, J. (2019). The globalization risk premium. Journal of Finance, 74(5), 2391-2439.

24. Blader, S., Gartenberg, C., Prat, A. (2020). The contingent effect of management practices. Review of Economic Studies, 87(2), 721-749.

25. Papanastassiou, M., Pearce, R., Zanfei, A. (2020). Changing perspectives on the internationalization of R\&D and innovation by multinational enterprises: A review of the literature. Journal of International Business Studies, 51(4), 623-664. 